\title{
Bio-digestion and post-treatment of effluents by bio-fermentation, an opportunity for energy uses and generation of organic fertilizers from bovine manure
}

\author{
Luis Antonio Barzallo-Bravo' ${ }^{1}$ David Carrera-Villacrés ${ }^{1,2} \cdot$ Rafael Eduardo Vargas-Verdesoto $^{3}$. \\ Lourdes Karina Ponce-Loaiza ${ }^{3} \cdot$ Modesto Correoso $^{2} \cdot$ Álvaro Petronio Gavilanes-Quishpi $^{3}$
}

Received: 10 September 2018 / Accepted: 1 June 2019 / Published online: 6 June 2019

(C) The Author(s) 2019

\begin{abstract}
Purpose Bio-fermentation has been routed as a viable alternative for the treatment of organic waste, which can provide renewable energy and can return nutrients to the soil with its byproducts. In this context, the objectives of the research were to analyze the benefits that a plastic plug-flow bio-digester can provide for treatment of bovine manure; and through biofermentation to control the $E$. coli number present in the bio-digester effluents.

Methods The concentration of macronutrients and amount of the $E$. coli in the effluent was determined by the methods of analysis purposed by APHA standard methods and AOAC standard methods, respectively. In addition, the percentage composition of biogas was analyzed for determining the operative of the system.

Results The production of biogas showed of $52.55 \%$ mol of methane concentration which it fed one blowtorch and one kitchenette. The bio-digester effluents showed appreciable amounts of nitrogen, potassium, phosphates, calcium, magnesium and sodium but with $E$. coli presence; the reason why the bio-digester effluent was treated later by a second fermentation inoculated with mountain effective microorganism, post-treatment which eliminated in $100 \%$ E. coli presence.

Conclusion Both processes showed the viability as treatment of the bovine manure which brings renewable energy and effluents with nutritive loads to use it as a biofertilizer without risks to health and humanity. The project was located at the tropical zone into the Choco forest, at an average altitude of $1110 \mathrm{~m}$ above sea level and an average temperature annual of $21-22^{\circ} \mathrm{C}$.
\end{abstract}

Keywords Plastic plug-flow bio-digester $\cdot$ Biogas $\cdot$ E. coli $\cdot$ Biofertilizers $\cdot$ Mountain effective microorganisms

\section{Introduction}

Due to the environmental degradation caused by anthropogenic activities and the population growth, which will have increased by two billion more people by 2050 (United Nations and CEPAL 2016); food resources and energy

Luis Antonio Barzallo-Bravo

luisbarzallobravo@gmail.com

1 Facultad de Ingeniería en Geología, Minas Petróleos y Ambiental (FIGEMPA), Carrera de Ingeniería Ambiental, Universidad Central del Ecuador, Av. Universitaria, Quito, Ecuador

2 Departamento de Ciencias de la Tierra y la Construcción, Universidad de las Fuerzas Armadas ESPE, Av. Gral. Rumiñahui S/N, Sangolquí, Ecuador

3 Departamento de Biotecnología, Universidad de las Fuerzas Armadas ESPE, Av. Gral. Rumiñahui/N, Sangolquí, Ecuador sources have been raised around the world as prevailing concerns for the new millennium.

To solve these concerns intensive agriculture or green agriculture was developed; it produced larger amounts of food in smaller areas of land, but with serious consequences of contamination of soil, surface water, and groundwater; as in the case of the Valencian community where $60 \%$ of its wells registered nitrate values higher than $50 \mathrm{mg} \mathrm{NO}_{3}^{-} / \mathrm{L}$ (Ribó-Herrero 2004) because of the leaching effect of inorganic fertilizers used intensively.

Whether it is added breeding of ruminant animals, which is responsible for emitting 35-40\% of anthropogenic methane annually (Steinfeld et al. 2006) with the environmental problem generated by the organic waste in the agricultural sector, the sought solutions should go by the hand with goal seven and goal two of the 2030 agenda for Latin America and the Caribbean, which promote the access of a 
sustainable energy and developing a sustainable agriculture, respectively (United Nations and CEPAL 2016).

Bio-digesters are framed of those objectives with providing renewable energy thanks to it can capture the methane, which is produced in the enteric fermentation of ruminants, with treating the bovine manure; and with its effluents it returned nutrients to the soil as organic fertilizer (PérezPérez et al. 2016), without allowing the accumulation and the escape of nitrogen in small farmland (Koneswaran and Nierenberg 2008); because the effluents are a very appreciated by-product for the fertilization of fields, by its fermentation process.

The process known specifically as methanogenic fermentation in which the organic matter is decomposed by anaerobic microorganisms in four contiguous phases; the organic molecules composed of several carbons are synthetized up to molecules composed of a single carbon such as $\mathrm{CH}_{4}$ and $\mathrm{CO}_{2}$ (Dublein and Steinhauser 2008; MIERGIA/PNUD/ FAO/GEF 2011).

Bio-digesters have had great worldwide development since the 1950s as an affordable energy and as a response to climate change mitigation; 7 million bio-digesters were approximately implemented from 1973 to 1983 in the rural localities of China, and for the 200520 million of bio-digesters were in operation; in India 2.5 million biogas plants were registered in 2008 (Dublein and Steinhauser 2008). But the initiative in Latin America for this same year was not very encouraging (Dublein and Steinhauser 2008); despite that the design of the flexible membrane bio-digester was promoted in Colombia, Costa Rica, Perú, Argentina, México, Chile and including Ecuador with more advances which the bio-digester launched in 1981 in Taiwan (Martí-Herrero 2011).

Despite the great advantages that flexible membrane bio-digesters or plastic plug-flow bio-digesters (PPFB) present, there still are limitations due to the presence of pathogens. This limitation is due to the work temperature handled because the plug-flow bio-digester does not have heating systems which control its temperature in the thermophilic range $\left(50{ }^{\circ} \mathrm{C}\right)$; range in which the presence of Coliforms and parasites is completely inhibited. In mesophilic ranges $\left(35^{\circ} \mathrm{C}\right)$ the reduction of Coliforms is estimated at $66 \%$ (FAO 1992), but the PPFBs does not reach neither of these two ranges of temperature. They commonly work at psychrophilic range $\left(25^{\circ} \mathrm{C}\right)$ which is not enough to eliminate the risk that the exponential value of Coliforms present (VIOGAS 2016) The reason why is suggested proper practices to use it or further treatment for bio-digester effluents (Yen-Phi et al. 2009).

As further treatment, bio-fermentation with mountain effective microorganism (MEM) is analyzed. Since this process intensifies the beneficial microbial activity with controlling the pathogen proliferation and it inhibits the microorganism which accelerate the putrefaction of organic material (Medina et al. 2015). In this process are generated some alcohols and lactic acids which promote $\mathrm{pH}$ decrease, and the organic materials become nutrients in better assimilation forms for plants (Campo-Martínez et al. 2014).

Additionally, the bio-fermentation is framed as a practice of sustainable agriculture for helping to maintain the local eco-systemic balance due to the mountain effective microorganisms are collected in the forest mulch of each region. They can be scattered in the same region where they are collected, and they help with the mineralization of elements and the formation of the organic matter of the soils (Argüello-Arias 1996) inside farmland.

The reason why the first objective was to analyze the viability of implementation of a plastic plug-flow bio-digester in a small dairy farm; assessing the compound and quantitative of biogas generated, assessing the macronutrient content into the effluent and assessing whether the Coliforms present in the bio-digester effluent comply with World Health Organization guide, that suggested the effluents might have less 1000 E. coli $/ 100 \mathrm{~mL}$ for irrigation of wastewater without restriction (WHO 2006). It will not comply with this regulation; a post-treatment effluent would be practice for complying it. The reason what the second research objective was raised, and it was to assess a bio-fermentation with mountain effective microorganism as post-treatment to reduce the $E$. coli number. Because in rural areas it is usual gather MEM and added them into biofertilizer, but existing reports are few which talk about the skill of MEM for treatment wastewater, Bio-digestion and bio-fermentation were chosen as alternatives for the treatment of bovine manure; taking to account the rural socio-economic reality in which the project was implemented. And both alternatives must have been affordable and technologies of easy application.

\section{Methods}

\section{Experimental site}

The research was conducted inside the facilities of a dairy farm which keeps seven calves stabled and nine cows in milking production; characterizing it as a small-scale farm. The farm located in San Miguel de los Bancos, province of Pichincha, into the Choco forest of Ecuador. The forest extends through Panama, Colombia, Ecuador and Perú.

For editing a map (Fig. 1) with the coordinates of the farm boundaries (Table 1) was utilized geographical information of the Instituto Espacial Ecuatoriano (2013) and the tools provided by the package QGis 2.18.16.

The canton is in the foothills of the Andes mountain range, the reason why the weather tends to be from a rainy wet forest (GAD municipal de San Miguel de los Bancos 
Fig. 1 Location and boundaries of the farm

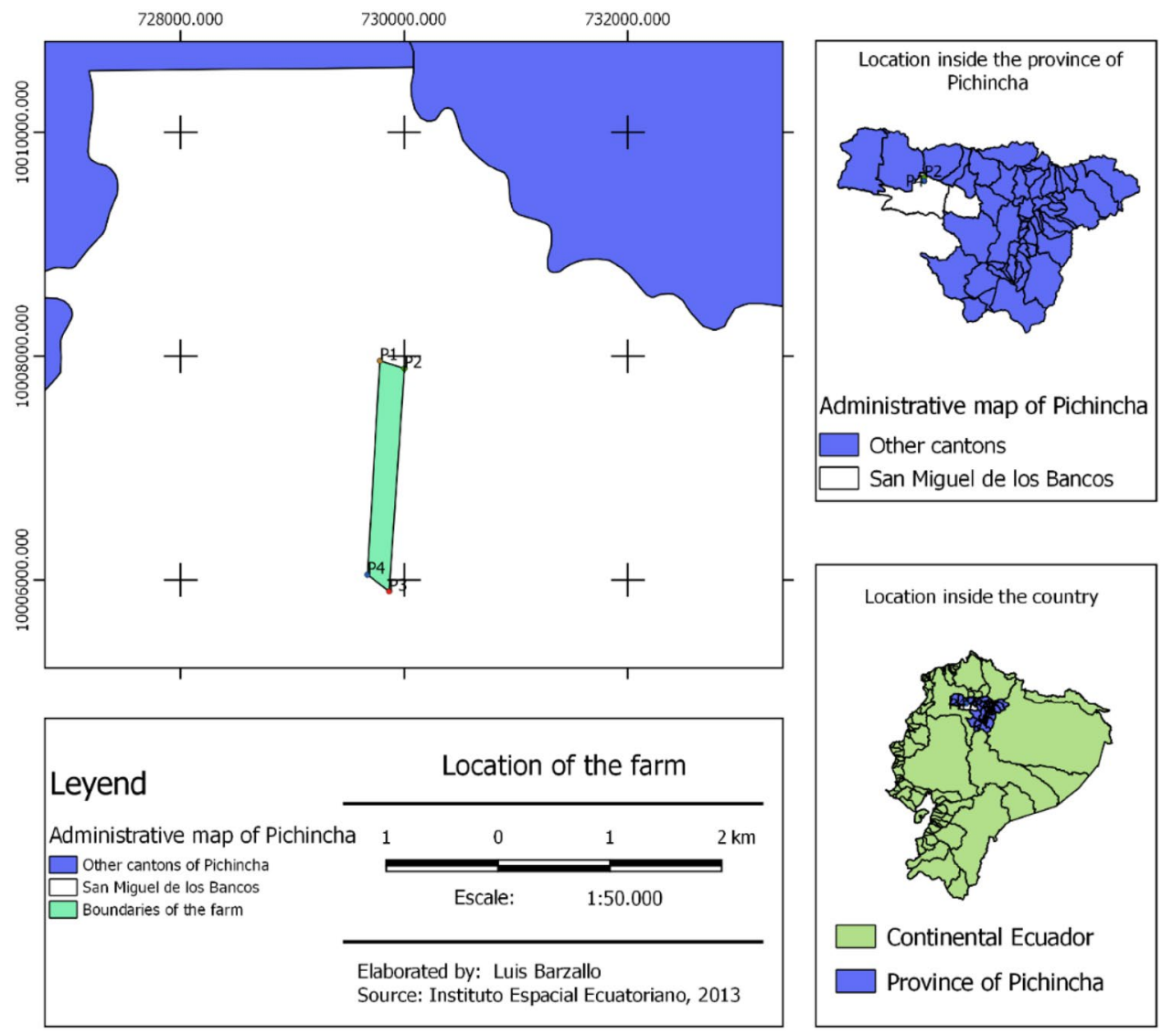

Table 1 Boundaries of the farm

\begin{tabular}{llll}
\hline Id. Punto & $X(\mathrm{UTM})$ & $Y(\mathrm{UTM})$ & Datum $y$ reference system \\
\hline P1 & 729,785 & $10,007,958$ & WGS84 Zona 17S \\
P2 & 730,002 & $10,007,890$ & WGS84 Zona 17S \\
P3 & 729,867 & $10,005,898$ & WGS84 Zona 17S \\
P4 & 729,671 & $10,006,046$ & WGS84 Zona 17S \\
\hline
\end{tabular}

2013). According to the maps downloaded from the Instituto Espacial Ecuatoriano portal web (2013); in the farm the average precipitation is between 4000 and $4100 \mathrm{~mm}$ for an area of 19.1 ha and 3900-4000 mm for an area of 22.6 ha. The average temperature is $21-22{ }^{\circ} \mathrm{C}$ in the 41.7 ha of the farm.

\section{Operation conditions and experimental units}

Inside of the farm a plastic plug-flow bio-digester (PPFB) was implemented with a length of $11.4 \mathrm{~m}$, a diameter of $1.6 \mathrm{~m}$ and with a volumetric capacity of $22.9 \mathrm{~m}^{3}$. The three-fourths of the PPFB volume stored water with bovine manure and the one-fourth remaining stored the biogas; volumetric proportion suggested by Martí-Herrero (2008) for constructing this type of biodigester. In addition, an extern biogas reservoir was adapted with 5:1 volume proportion between bio-digester volume and reservoir volume.

Nearby at the bio-digester a tank of $80 \mathrm{~L}$ was adapted a tank for second fermentation (TSF) process; in the tank lid one half inch hole was done to connect: a tank adapter, 45th elbow of half inch and stopper of half inch. This conditioning was created to release the gas accumulated from fermentation, because a good fermentation needs an anaerobic system that is totally air tight. For validating the air tightness in the tank, the gas accumulation was observed through a bio-fermentation of molasses. Action realized two consecutive times (Fig. 2).

Bio-fermentation was realized with a dissolution of $1.89 \mathrm{~L}$ of molasses with $50 \mathrm{~L}$ of water mixing with $17 \mathrm{~kg}$ of primary forest mulch. It is the inoculum of bacteria and fungi commonly called mountain effective microorganisms or MEM (Cruz 2010) which decompound the organic matter and return the nutrients to the soil into the forest (CATIE 2012).

TSF was let ferment with molasses, water and forest mulch for 15 days, the surplus gas was release when uncovering the stopper. Then the TSF was fed with $15 \mathrm{~L}$ of the bio-digester effluent for two times every 7 days until gauged 


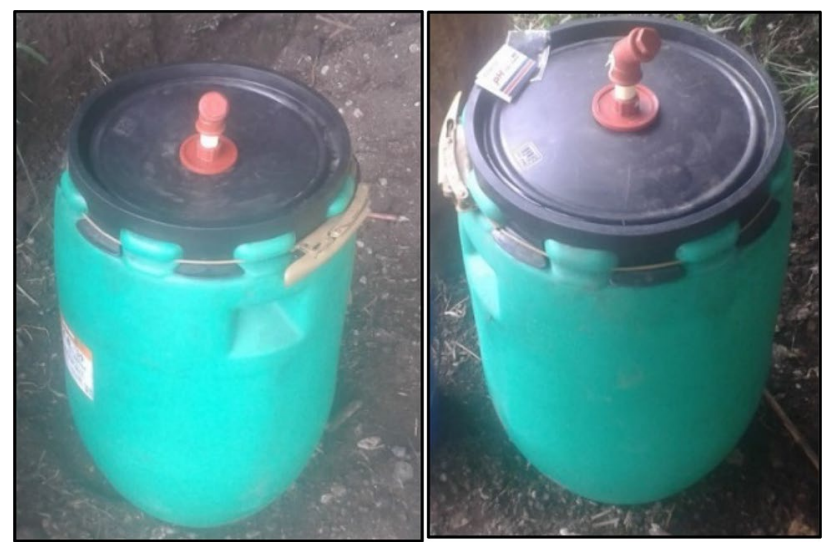

Fig. 2 Air tightness test for TSF

it. Once gauged, it was left to ferment for 7 days more before for taking a sample and carry it to the laboratories.

\section{Chemical and microbiological analysis}

The sampling method utilized for the chemical analyzes of the plug-flow bio-digester effluents (PFB-E) was simple random sampling; samples that was taken by 63 days. Seven samples were analyzed which of one was discarded because it had chemical values more dispersed than the other samples. The sampling was realized in the $31,38,42,53,59$, and 63 day. We started sampling at 30 day taking in account the biogas production has peaks at this time (Yen-Phi et al. 2009).

The sampling method utilized for the chemical analyses of effluents of the tank for a second fermentation (E-TSF) was the judgment sampling; the final point for take a sample was established when the liquid got a $\mathrm{pH} \leq 4$ (Medina et al. 2015) This $\mathrm{pH}$ was got coincidentally 7 days after the tank gauged.

We analyzed all effluent samples inside the environmental engineering laboratories which belong to the Facultad de Ingenierías en Geología Minas Petróleos y Ambiental of the Universidad Central del Ecuador. Only the parameters of temperature and $\mathrm{pH}$ was measured in situ; for measuring
pH we utilized pH tests strips Macherey \& Nagel Ref 921 10.1 and for determining the temperature we used a digital thermometer with an appreciation of $\pm 0.1{ }^{\circ} \mathrm{C}$.

The chemical parameters analyzed for PFB-E and E-TSF were total nitrogen, calcium, magnesium, sodium, potassium and phosphate (Table 2). Each equipment used had a white sample and it did the self-calibration curve before the measurement of each parameter; all of this for reliability of data obtained.

For the microbiological analysis of the PFB-E and E-TSF, PetrifilmTM plates of the commercial company $3 \mathrm{M}$ were used. The plates were allowed to count colony forming units (CFU) by the color change of the medium where colonies of coliform were red and E. coli colonies were blue. The method is validated for the official method 991.14 of the Association of Official Analytical Chemists (AOAC).

Referring the biogas analysis; a sample was directly taken from the biogas reservoir, the sample was sent to the investigation area of the career-Chemistry engineering of the Universidad Central del Ecuador. The type of test performed was gas chromatography under the methodology/ RGA/ASTM D-1945/ASTM D-1946.

\section{Descriptive statics of the samples}

Seven samples of effluents were taken of the plug-flow biodigester to calculate their mean, typical error, median, range, minimum, and maximum of the macronutrients content; and one sample was taken of the tank of second fermentation (Table 3) Microsoft Excel 2016 was used to calculate the central tendency and to plot the relation of $\mathrm{pH}$ vs number of E. coli presented in Fig. 4.

\section{Results and discussion}

The installation of plastic plug-flow bio-digester (PPFB) demonstrated the viability of applying this technology in small scale farm in contrast that the knowledge of biodigester projects only are economically viable for big farms. Because it works at environmental temperature which

Table 2 Chemical parameter and methods utilized

\begin{tabular}{ll}
\hline Parameter & Methodology \\
\hline Kjeldahl digestion & Digesdahl-HACH digestion method \\
Total nitrogen & Spectrophotometry method 4500-N (American Public Health Association APHA 2005) \\
Calcium & Titrimetric method 2340 C (American Public Health Association APHA 2005) \\
Magnesium & Titrimetric Method 2340 C (American Public Health Association APHA 2005) \\
Phosphate & Spectrophotometry method 4500-PO ${ }_{4}^{3-}$ (American Public Health Association APHA 2005) \\
Sodium & Atomic absorption spectrometry method 3110 (American Public Health Association APHA 2005) \\
Potassium & Atomic absorption spectrometry method 3110 of the (American Public Health Association APHA 2005)
\end{tabular}


Table 3 Static analysis carried out of the sample effluents

\begin{tabular}{lllll}
\hline Type of effluent & $\begin{array}{l}\text { Number of } \\
\text { samples }\end{array}$ & $\begin{array}{l}\text { Descriptive stat- } \\
\text { ics of tempera- } \\
\text { ture }\end{array}$ & Descriptive statics of pH & $\begin{array}{l}\text { Descriptive statics: nitrogen, phosphates, potassium, cal- } \\
\text { cium, magnesium, sodium }\end{array}$ \\
\hline $\begin{array}{c}\text { Plug-flow bio- } \\
\text { digester effluent } \\
(\text { PFB })\end{array}$ & 7 & Mode & Mode & Mean, median, range, typical error, minimum and maximum \\
$\begin{array}{c}\text { Tank of second } \\
\text { fermentation } \\
\text { Effluent (TSF-E) }\end{array}$ & 1 & $\begin{array}{c}\text { Value of } \\
\text { temperature }\end{array}$ & Value of $\mathrm{pH}^{\mathrm{a}}$ & Value of macronutrients $^{\mathrm{a}}$ \\
\hline
\end{tabular}

${ }^{\mathrm{a}}$ It is the direct value measure without statistical calculation

Table 4 Percentage composition of biogas sample produced in PPFB

\begin{tabular}{ll}
\hline Gaseous compounds & $\% \mathrm{~mol}$ \\
\hline Methane & 52.6 \\
Hydrogen & 17.7 \\
Oxygen & 0.0371 \\
Nitrogen & 13.4 \\
No identified & - \\
Carbon dioxide & 6.45 \\
No identified & - \\
\hline
\end{tabular}

decrease operating cost and investment costs of the system. Even if plug-flow bio-digester effluent have E. coli, the posttreatment with mountain effective microorganism (MEM) was successful which allowed to eliminated $E$. coli, become a good alternative to stabilize bovine manure in little period, and obtain new benefit of effluent treated as biofertilizer.

\section{Bio-digester operating}

The plastic plug-flow bio-digester (PPFB) maintained $21.4^{\circ} \mathrm{C}$ as average work temperature which found in the maximum psychrophilic range (Lagrange 1979) because it worked at environmental temperature without heating systems. The $\mathrm{pH}$ mode was 8 which matches with the $\mathrm{pH}$ range of 6.0-8.3 reported by Sosa (2015) who assessed eight small scale biodigester. So the PFB did not need $\mathrm{pH}$ controls as it was framed within the optimal range of 7.8-8.2, for the development of the methanogenic microorganisms (MIERGIA/PNUD/FAO/GEF 2011). Development that was validated by a biogas production of $52.55 \%$ mol of methane content (Table 4). Acceptable methane content taking in account that Dublein and Steinhauser (2008) referred a $55 \%$ mol methane as general feature composition of biogas, and it was higher than the minimum methane content to be flammable which is $45 \%$. Bio-digester has demonstrated the feasibility of the use with a good methane production (Njuguna et al. 2018).
Becoming an affordable alternative for rural areas because it works without active devices or heating system (Martí-Herrero 2011) which decreases the operating cost. Contrasting the statement which Koneswaran and Nierenberg supported that anaerobic digesters are not economically viable (2008).

The daily biogas outputs were estimated as $4.20 \mathrm{~m}^{3} /$ day which was verified by keeping full biogas reservoir; the reservoir biogas had $4.75 \mathrm{~m}^{3}$ of volume. The biogas production estimated in liter per kilogram of manure feed, and per day of the bio-digester was $0.93 \mathrm{~L} / \mathrm{kg} /$ day which is higher than the production reported by Pandey and Sopir (2012) whom achieved $0.12 \mathrm{~L} / \mathrm{kg} /$ day with a thermophilic batch biodigester.

With the biogas produced, it could feed a kitchenette and blowtorch for more than $5 \mathrm{~h}$ uninterruptly. According to Martí-Herrero (2008) who sustain a kitchen consumes $170 \mathrm{~L} / \mathrm{h}$ approximately; with the current biogas production can feed the kitchen for $24 \mathrm{~h}$; or it can produce $6.48 \mathrm{~kW} /$ day if the biogas connects to a thermal transformer which consumes 620 L/KW (CEPIS 1996).

The plug-flow bio-digester effluent (PFB-E) showed measurable number of macronutrients in $\mathrm{mg} / \mathrm{L}$. The average values were: 751 total nitrogen $\mathrm{mg} / \mathrm{L}, 15.3$ phosphate $\mathrm{mg} / \mathrm{L}$, 114 potassium mg/L, 253 Calcium mg/L, 180 Magnesium $\mathrm{mg} / \mathrm{L}$ and 74.2 sodium $\mathrm{mg} / \mathrm{L}$ (Table 5 ). But by the presence of Coliforms in the PFB-E same results that got Yet-Phi et al. who suggested that hydraulic relation of time of 30 days are not enough to meet with the advice of WHO (2006) for founding it without restriction to use.

The number of $E$. coli was in the range of $7.00 \times 10^{5}-2.00 \times 10^{5} \mathrm{CFU} / 100 \mathrm{~mL}$. Range outside of the $1 \times 10^{3}$ E. coli/100 mL suggested by WHO for agricultural use without restriction (2006). But in the research, the number of $E$. coli was reduced when existed a decrease of $\mathrm{pH} 8$ to $\mathrm{pH} 7$ (Fig. 3). This can be explained because E. coli are adapted to alkaline medium which are provided by (PeraltaVeran et al. 2016). And their growth slowed down with a shift in their external $\mathrm{pH}$ due to the relation existing between 
Table 5 Macronutrient content of the bio-digester effluents

\begin{tabular}{lllllll}
\hline Descriptive statistics & $\begin{array}{l}\text { Total nitrogen } \\
(\mathrm{mg} / \mathrm{L})\end{array}$ & $\begin{array}{l}\text { Phosphates } \\
(\mathrm{mg} / \mathrm{L})\end{array}$ & $\begin{array}{l}\text { Potassium } \\
(\mathrm{mg} \mathrm{K} / \mathrm{L})\end{array}$ & $\begin{array}{l}\text { Calcium } \\
(\mathrm{mg} / \mathrm{L})\end{array}$ & $\begin{array}{l}\text { Magnesium } \\
(\mathrm{mg} / \mathrm{L})\end{array}$ & $\begin{array}{l}\text { Sodium } \\
(\mathrm{mg} / \mathrm{L})\end{array}$ \\
\hline Mean & 752 & 15.4 & 114 & 253 & 180 & 74.2 \\
Typical error & 68.6 & 11.74 & 3.23 & 21.2 & 40.5 & 14.1 \\
Median & 780 & 2.08 & 115.4 & 247 & 166.05 & 60.4 \\
Range & 495 & 72.56 & 20.13 & 147 & 280.26 & 90.3 \\
Minimum & 448 & 0.720 & 102 & 200 & 64.8 & 51.8 \\
Maxim & 943 & 73.3 & 121.63 & 347 & 345.06 & 142 \\
\hline
\end{tabular}
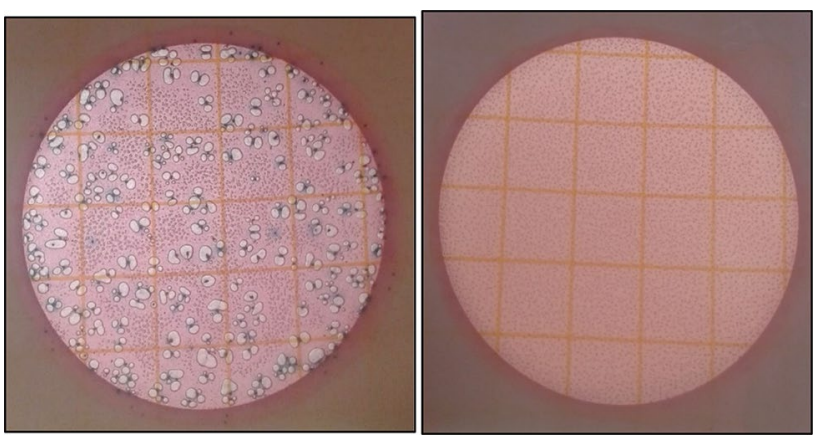

Fig. 3 E. coli and $\mathrm{pH}$ of the PPFB-E

membrane $\mathrm{H}+$ conductance and the $\mathrm{pH}$ of the growth medium (Akopyan and Trchounian 2006).

The reason why a second fermentation was chose such as solution, and following the suggestion of other authors which prompt a post-treatment the bio-digester effluent (Yen-Phi et al. 2009; Velho et al. 2012) It was practiced a fermentation with mountain effective microorganism as alternative to control the number of $E$. coli present inside of the PFB-E,

\section{Bio-fermentation of effluents with mountain effective microorganism}

E. coli and Coliforms present in the plug-flow bio-digester effluents (PFB-E) was eliminated in $100 \%$, can be seen how in Fig. 4. Thanks to the second fermentation practiced with mountain effective microorganism (MEM). This phenomenon can explained with the growth of lactic acid bacteria (LAB), yeast and phototropic bacteria that became antagonism microorganisms. Because LAB effectively fermented carbohydrates existent in the effluent, and they produced enough quantities of lactic acids, acetate, ethanol, succinate and formate (Hammes and Hertel 2009) which allowed to decrease $\mathrm{pH}$ inside the tank of second fermentation (TSF) and inhibited the growth of pathogen bacteria (Vandenverg 1993) Due to few microorganism are adapted to live with this growth-inhibiting factors (Servin 2004) and it is the main mechanisms of microbial antagonism to impede the
Fig. 4 Coliforms in the PPFB-E (left) and Coliforms in the E-TSF (right)

growth of Coliforms which are naturally developed in alkaline mediums inside an animal digest tract (Peralta-Veran et al. 2016; Rashid and West 2007).

Another factor that could take the credit of eliminating coliform bacteria, and other authors suggested, it could be the bacteriocins generated by LAB. Due to the bacteriocins have antimicrobial activity which can inhibit the growth of bacteria which do not have a similar metabolism system to resist it (Vandenverg 1993; Servin 2004; Alvarez-Sieiro et al. 2016; Adetoye et al. 2018) The elimination of E. coli was more successful than the research of Rashid and West (2007) whom obtained a decrease of $95 \%$ of fecal Coliforms with the use of effective microorganism.

The decrease of $\mathrm{pH}$ since 7.0 to 4.0 was achieved in only 7 days with helping of MEM. Result that was close to the work of Peralta-Veran et al. (2016) whom accomplished a $\mathrm{pH}=4.02$ in 5 days with a consortium of lactic acid bacteria. The importance of this post-treatment was the efficiency and viability the treatment, it only does not for its cheap and easy acquisition of materials; how are the molasses and forest mulch with mountain effective microorganism (MEM), but also the post-treatment eliminated the risk for human health that $E$. coli presented before. It becomes as a good alternative for treatment of bovine wastewater in a little period in comparison with other alternatives of stabilization of bovine manure (Peralta-Veran et al. 2016) And it allows to obtain 
Table 6 Comparison of the macronutrient load between the effluent produced in bio-digester and the effluent produced in the tank of second fermentation with MEM

\begin{tabular}{llllllr}
\hline Effluent & $\begin{array}{l}\text { Total nitrogen } \\
\mathrm{mg} / \mathrm{L}\end{array}$ & $\begin{array}{l}\text { Phosphates } \\
\mathrm{mg} / \mathrm{L}\end{array}$ & $\begin{array}{l}\text { Potassium } \\
\mathrm{mg} / \mathrm{L}\end{array}$ & $\begin{array}{l}\text { Calcium } \\
\mathrm{mg} / \mathrm{L}\end{array}$ & $\begin{array}{l}\text { Magnesium } \\
\mathrm{mg} / \mathrm{L}\end{array}$ \\
\hline PFB-E & 752 & 15.4 & 114 & 253 & $\begin{array}{l}\text { Sodium } \\
\mathrm{mg} / \mathrm{L}\end{array}$ \\
E-TSF & 500 & 221.87 & 111 & 500.00 & 180 & 101.25 \\
\hline
\end{tabular}

a new benefit with the effluent treated as organic fertilizer (Cruz 2010).

Due to the post-treated effluent maintain appreciable content of mineral, how can see in the Table 6 , and where is presented a comparison between macronutrients constituent of PFB-E and the effluent of the tank of the second fermentation (E-TSF). Where can appreciate a less decrease of total nitrogen, potassium and magnesium: with values of $500 \mathrm{mg}$ $\mathrm{TN} / \mathrm{L}, 111.00 \mathrm{mg} \mathrm{K} / \mathrm{L}$ and $101.25 \mathrm{mg} / \mathrm{L}$, respectively; but an increase of content of phosphate, calcium and sodium with values of $221.87 \mathrm{mg} \mathrm{PO}_{4}{ }^{3-} / \mathrm{L}, 196.8 \mathrm{mg} \mathrm{Na} / \mathrm{L}, 500 \mathrm{mg} \mathrm{Ca} / \mathrm{L}$ since molasses contributed more nutrients upon the effluents, similar results were reported by Medina et al. (2015) in their studies, and suggested the fermentation process gives better nutritive properties to the effluent. In comparison with other works, the macronutrients found in the effluent were the same (Peralta-Veran et al. 2016, Medina et al. 2015) but with quantitative differences. Therefore, the effluent constitution would be directly correlated with the diet of dairy cattle and nutrient content of raw materials treated (Criollo et al. 2011; Peralta-Veran et al. 2016) rather than the process used for treatment organic waste.

The post-treated effluent could stimulate the development of plants thanks to the work of MEM which are an antagonistic microorganism group as mention above. Because it also competes with phytopathogens of plants and suppression their growth for their fast proliferation and quick consumes of carbon, nitrogen and other nutrients of the soil (Fatunbi and Ncube 2009; Vásquez et al. 2009) Mineralizing the organic matter present in the soil and leaving nutrients in available forms for plants. Although in research cannot directly experiment in soil or with crops, but one example of this natural skills that MEM was demonstrated by Fatunbi and Ncube (2009) who achieved an increase of 51\% and 99\% of net mineralization of nitrogen in two different organic materials with helping of effective microorganism.

Taking in account the practice of post-treated wastewater with MEM, it is a viable alternative how the research showed. It could disseminate more people will worry about the primary forest existing inside the dairy farms, and they generate a better planification to conserve the forest and to extract benefit of it, such as the case of MEM, by the hand with the milk production.

\section{Conclusion}

The research showed the viability for implementing a plastic plug-flow bio-digester inside of small-scale farm for the treatment of bovine manure. The benefits were to produce biogas with $52.55 \%$ mol of methane content, which was burned and utilized as thermic energy inside the farm; action that reduces the negative impact which the free methane does in the environment and provides affordable energy. In addition, bio-digester effluents have a measurable content in hundreds of $\mathrm{mg} / \mathrm{L}$ of macronutrients, but with a $E$. coli range which was outside the suggestion of WHO for unrestricted wastewater use in agriculture. The reason why the effluent was treated with mountain effective microorganism by a second fermentation which eliminated $E$. coli presence and maintained content of nitrogen, potassium, calcium, magnesium, sodium and phosphate. Effluent post-treated by a second fermentation which became a biofertilizer without risk human health and the same time it provides the management of a sustainable agriculture.

Open Access This article is distributed under the terms of the Creative Commons Attribution 4.0 International License (http://creativeco mmons.org/licenses/by/4.0/), which permits unrestricted use, distribution, and reproduction in any medium, provided you give appropriate credit to the original author(s) and the source, provide a link to the Creative Commons license, and indicate if changes were made.

\section{References}

Adetoye A, Pinloche E, Adeniyi B, Ayeni F (2018) Characterization and anti-salmonella activities of lactic acid bacteria isolated from cattle faeces. BMC Microbiol 18:1-11. https://doi.org/10.1186/ s12866-018-1248-y

Akopyan K, Trchounian A (2006) Escherichia coli membrane proton conductance and proton efflux depend on growth $\mathrm{pH}$ and are sensitive to osmotic stress. Cell Biochem Biophys 46:201-208. https:// doi.org/10.1385/cbb:46:3:201

Alvarez-Sieiro P, Montalbán-López M, Dongdong M, Kuipers O (2016) Bacteriocins of lactic acid bacteria: extending the family. Appl Microbiol Biotechnol 100:2939-2951. https://doi. org/10.1007/s00253-016-7343-9

Argüello-Arias H (1996) Dinámica de la producción y descomposición del matillo de bosque muy húmedo tropical del bajo Calima, en el valle del Cauca. Agron Colomb 13:198-214 
Campo-Martínez A, Acosta-Sánchez R, Morales-Velasco S, Prado FY (2014) Evaluación de microorganismos de montaña (MM) en la producción de acelga en la meseta de Popayán. Biotecnol Sect Agropecu Agroind 12:79-87

Criollo H, Lagos T, Piarpuezan E, Pérez Ruth (2011) The effect of three liquid bio-fertilizers in the production of lettuce (Lactuca sativa L.) and cabbage (Brassica oleracea L. var. capitata). Agron Colomb 29:415-421

Dublein D, Steinhauser A (2008) Biogas from waste and renewable resources: an introduction. Wiley, Weinheim, Germany

FAO (1992) Biogas process for sustainable development. MIGAL Galilee Technological Centre, Kiryat Shmona

Fatunbi A, Ncube L (2009) Activities of effective microorganism (EM) on the nutrient dynamics of different organic materials applied to soil. Am Euroasian J Agron 2:26-35

Hammes W, Hertel C (2009) Bergey's manual of systematic bacteriology: volume three the firmicute. Springer, Berlin

Koneswaran G, Nierenberg D (2008) Global farm animal production and global warming: impacting and mitigating climate change. Environ Health Perspect 116:578-582. https://doi.org/10.1289/ ehp. 11034

Martí-Herrero J (2008) Biodisgestores familiares guía de diseño y manual de instalación. GTZ Energía, Bolivia

Martí-Herrero J (2011) Reduced hydraulic retention times in low-cost tubular digesters: two issues. Biomass Bioenerg 35:4481-4484. https://doi.org/10.1016/j.biombioe.2011.07.020

Medina VA, Quipuzco UL, Juscamaita MJ (2015) Evaluación de la calidad de biol de segunda generación de estiércol de ovino producido a través de biodigestores. An Cient 76:116-124. https:// doi.org/10.21704/ac.v76i1.772

MIERGIA/PNUD/FAO/GEF (2011) Manual de Biogás. Proyecto CHI/00/G32, Santiago

Njuguna A, Mbohwa C, Ntuli F, Belaid M, Seodigeng T, Ngila JC, Kinuthia C (2018) Waste to energy bio-digester selection and design model for the organic fraction of municipal solid waste. Renew Sustain Energy Rev 82:1113-1121. https://doi. org/10.1016/j.rser.2017.09.051

Pandey K, Soupir M (2012) Impacts of temperatures on biogas production in dairy manure anaerobic digestion. Int J Eng Technol 4:629-631. https://doi.org/10.7763/ijet.2012.v4.448

Peralta-Veran L, Juscamaita-Morales J, Meza-Contreras V (2016) Obtención y caracterización de abono orgánico líquido a través del tratamiento de excretas del ganado vacuno de un establo lechero usando un consorcio microbiano ácido láctico. Ecol Apl 15:1. https://doi.org/10.21704/rea.v15i1.577

Pérez-Pérez T, Pareda-Reyes I, Oliva-Merencio D, Zaiat M (2016) Anaerobic digestion technology for the treatment of pig manure. Cuba J Agric Sci 50:343-354
Rashid M, West J (2007) Dairy wastewater treatment with effective microorganisms and duckweed for pollutants and pathogen control. NATO Sci Peace Secur Ser. https://doi. org/10.1007/978-1-4020-6027-4_10

Ribó-Herrero M (2004) Balance de macronutrientes y materia orgánica en el suelo de agro-sistemas hortícolas con manejo ecológico integrado. Repositori de Contingut Lliure Universitat de València

Servin A (2004) Antagonistic activities of lactobacilli and bifidobacteria against microbial pathogens. FEMS Microbiol Rev 28:405440. https://doi.org/10.1016/j.femsre.2004.01.003

Sosa C (2015) Parámetros de control y monitoreo del proceso en digestores anaerobios de pequeña escala y diferentes tecnologías. Repositorio UCLV website

Steinfeld H, Gerber P, Wassenaar T, Castel V, Rosales M, de Haan C (2006) Livestock's long shadow: environmental issues and options. LEAD, Rome

United Nations, CEPAL (2016) Agenda 2030 y los objetivos de desarrollo sostenible Una oportunidad para América Latina y el Caribe. CEPAL, Santiago

Vandenverg P (1993) Lactic acid bacteria, their metabolic products and interference with microbial growth. FEMS Microbiol Rev 12:221-237. https://doi.org/10.1111/j.1574-6976.1993.tb00020.x

Vásquez S, Suárez H, Zapata S (2009) Utilización de sustancias antimicrobianas producidas por bacterias acido lácticas en la conservación de la carne. Rev Chi 36:64-71

Velho VF, Mohedano RA, Filho P, Costa RH (2012) The viability of treated piggery wastewater for reuse in agricultural irrigation. Int $\mathbf{J}$ Recycl Org Waste Agric 1:10. https://doi. org/10.1186/2251-7715-1-10

VIOGAS (2016) Biogás en el sector lechero en Chile. Ministerio de Energía, Chile

WHO (2006) WHO guidelines for the safe use of wastewater, excreta and greywater, volume 1: policy and regulatory aspects. WHO press, Geneva

Yen-Phi VT, Clemens J, Rechenburg A et al (2009) Hygienic effects and gas production of plastic bio-digesters under tropical conditions. J Water Health 7:590-596. https://doi.org/10.2166/ wh.2009.127

Publisher's Note Springer Nature remains neutral with regard to jurisdictional claims in published maps and institutional affiliations. 